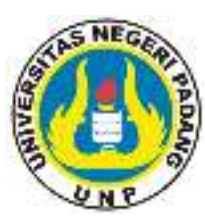

\title{
ANALISIS KESALAHAN PENGGUNAAN DOUSHI DAN KEIYOUSHI PADA SAKUBUN MAHASISWA PRODI PENDIDIKAN BAHASA JEPANG UNP
}

\author{
Indah Marlina ${ }^{1}$, Meira Anggia Putri ${ }^{2}$ \\ ${ }^{1}$ (Mahasiswa Pendidikan Bahasa Jepang, Bahasa dan Sastra Inggris, Fakultas Bahasa \\ dan Seni, Universitas Negeri Padang) Jl. Prof. Dr. Hamka Air Tawar, Padang 25131 \\ ${ }^{2}$ (Dosen Pendidikan Bahasa Jepang, Bahasa dan Sastra Inggris, Fakultas Bahasa dan Seni, \\ Universitas Negeri Padang) Jl. Prof. Dr. Hamka Air Tawar, Padang 25131
} Email Penulis : indahmarlina37@gmail.com

\begin{tabular}{ll}
\hline \multicolumn{3}{l}{ Sejarah Artikel } \\
\hline Submit $: 2020-10-30$ \\
Diterima $: 2020-11-02$ \\
Diterbitkan $:$ 2021-06-09
\end{tabular}

\section{Abstrack}

This research discusses about analysis of error in using doushi and keiyoushi on the college student of japanese language education program, Padang state university. The purpose of this research to describe form

\section{Kata Kunci:}

Analysis, keiyoushi, doushi , mistake, sakubun and types of error in using doushi and keiyoushi on college students entering 2019 of japanese language education program, padang state university. In this reseach the types of the research that used is qualititative research with descriptive method. The data in this research is error using doushi and keiyoushi in the sentences that countained in the data sourcase like sakubun college student entering 2019 japanese language education program, UNP amount 30 sakubun. Instrument on this research is the researcher. Base on the research using doushi, it can be concluded that there are 9 forms of phonological errors, 8 morphological errors, and only 7 syntactic errors. Then in Doushi there are 14 types of errors, 9 lapses. It can be concluded that the form of phonological errors has 18 errors, 2 morphological errors, 12 syntactic errors, and 2 semantic errors. Furthermore, there are 25 types of errors, and 8 lapses.

(C2020 The Author(s) Publish by Jurusan Bahasa dan Sastra Inggris FBS UNP. This is an open access article under the CC-BY-NC license (https://creativecommons.org/licenses/by-nc/4.0/) 


\section{PENDAHULUAN}

Alat yang dipakai oleh masyarakat guna mengantarkan pikiran, gagasan, serta perasaan kepada masyarakat lain ialah bahasa. Soepardjo (2012: 1-2) menyatakan bahwa bahasa yaitu suatu aturan yang dipakai oleh manusia ataupun sebagai alat untuk berkomunikasi antara sesama manusia secara lisan ataupun secaratulisan. Di Indonesia sudah diajarkan berbagai macam bahasa asing, salah satunya ialah bahasa Jepang.

Bahasa Jepang mempunyai berbagai karakteristik yang dapat dilihat dari aspek kebahasaannya. Karakteristik tersebut bisa dilihat pada huruf yang dipakai, kosa kata, pola kalimat, dan juga pada ragam bahasa nya. Salah satu unsur yang penting pada bahasa Jepang yakni kosakata, untuk bahasa Jepang dikenal degan istilah goi.

Pada goi terdapat beberapa kelas pada kata yang bisa membedakan antar satu kata dengan kata yang lainnya. Pada linguistik, menurut Zalman (2014: 19) kelas kata bahasa Jepang tersebut disebut dengan hinshi bunrui. Hinshi bunrui tersebut terdiri atas: kata kerja yang disebut doushi, kata sifat yang disebut keiyoushi, kata benda yang disebut meishi, kata keterangan yang disebut fukushi, partikel yang disebut joshi, serta kopula yang disebut jodoushi. Di antara 3 (tiga) dari hinshi bunrui yang memiliki perubahan bentuk tersebut, yang merupakan hinshi bunrui yang dapat berdiri sendiri yang disebut jiritsugo ialah keiyoushi dan doushi.

Menurut Sutedi (2003: 49) keiyoushi adalah rasa, sifat, keadaan sesuatu yang berhubungan dengan manusia, benda ataupun sesuatu yang diutarakan melalui katakata. Ada dua macam keiyoushi dalam bahasa Jepang, yaitu keiyoushi atau Ikeiyoushi yang berakhiran huruf [ / / i], dan keiyoudoushi atau na-keiyoushi yang berakhiran huruf [な / na]. Kedua bentuk keiyoushi di atas memiliki perubahan dalam bentuk negatif, positif lampau, negatif lampau dan keiyoushi yang di hubungkan dengan kata benda. I-keiyoushi dan na-keiyoushi bentuk perubahannya berbeda-beda. Begitu pula dengan doushi.

Menurut Sudjianto dan Dahidi (2004:149) doushi yaitu salah satu kelas kata yang digunakan buat melaporkan kegiatan, keberadaan atau kondisi sesuatu. Doushi dikelompokkan jadi beberapa bagian kelompok, dan juga mempunyai perubahan pada bentuknya. Ketentuan pada pergantian doushi dipengaruhi oleh kelompok doushi. Doushi dikelompokkan jadi tiga kelompok utama, yakni doushi kelompok I, doushi kelompok II, serta doushi kelompok III.

Berbagai macam perubahan bentuk pada keiyoushi dan doushi menjadikan terdapat potensi yang lumayan tinggi yang bisa menjadikan terdapatnya kesalahan pada pemakaiannya. Artinya, beberapa aturan yang berbeda dalam perubahan keiyoushi dan doushi yang akan membuat pelajar kesulitan dalam mempelajarinya sehingga pelajar sering melakukan kesalahan.

Berdasarkan wawancara yang telah peneliti lakukan kepada mahasiswa angkatan 2019 Program Studi Pendidikan Bahasa Jepang, Universitas Negeri Padang, para mahasiswa mengatakan bahwa mereka kurang mengerti tentang keiyoushi dan doushi. Untuk hasil dari wawancara yang sudah di lakukan, dapat disimpulkan bahwa sebahagian besar mahasiswa menganggap bahwa keiyoushi dan doushi itu sulit. 
Penggunaan keiyoushi dan doushi terdapat dalam berbagai mata kuliah yang ada dalam program studi pendidikan bahasa Jepang, salah satunya ialah mata kuliah sakubun. Sakubun adalah sebuah karangan dalam bentuk bahasa Jepang. Sumber data pada penelitian ini ialah sakubun dikarenakan pada sakubun tersebut terdapat potensi kesalahan mahasiswa yang lebih besar. Sutedi dalam Annisac (2018: 69), mengatakan kalau mata kuliah sakubun kerap dikira mata kuliah yang sangat susah untuk pembelajar. Sulitnya menulis sebuah karangan dalam bahasa Jepang dikarenakan banyaknya unsur kemampuan yang harus dimiliki membuat pembelajar bahasa Jepang memiliki potensi yang lebih besar untuk melakukan kesalahan. Beberapa kesalahan yang cukup sering ditemukan dalam sakubun adalah kesalahan penggunaan keiyoushi dan doushi. Kesalahan dalam penggunaan keiyoushi dan doushi pada sakubun termasuk ke dalam kesalahan berbahasa.

Tarigan dan Tarigan (2011: 152) mengklasifikasikan kesalahan berbahasa berdasarkan bentuknya dalam tataran linguistik menjadi 4 bidang yaitu fonologi, morfologi, sintaksis, dan semantik. Sutedi (2003: 37, 43, 64, 127) menyatakan bahwa yang pertama, istilah fonologi yaitu 'on iron' yang berarti cabang linguistik yang mengaji tentang lambang pada bunyi bahasa berdasarkan guna. Yang kedua, morfologi 「形態論 'keitairon’」 yakni cabang linguistik yang mengkaji tentang kata serta peroses pembentukan nya dengan objek nya yakni kata 「語 ' $g o$ ' atau 'tango'単語」 dan morfem 「形態素 'keitaiso'」. Kemudian yang ketiga, sintaksis pada bahasa Jepang di sebut juga dengan 'tougoron'「統語論」 ataupun 'sintakusu' 「シンタクス, yakni bagian pada linguistik yang mengkaji mengenai struktur serata unsur-unsur pembentukannya. Dan yang terakhir adalah semantik pada bahasa Jepang di sebut juga dengan imiron, yakni bagian linguistik yang mengkaji tentang arti.

Selain klasifikasi kesalahan berbahasa berdasarkan bentuknya, terdapat pula pengklasifikasian kesalahan berbahasa menurut jenisnya. Corder (dalam Hazni, 2017: 22) mengatakan bahwa ada tiga jenis pada kesalahan berbahasa yakni mistake, lapses, dan error. Mistake (salah) ialah penyimpangan struktur yang terjalin sebab penutur tidak sanggup memastikan opsi pemakaian ungkapan yang pas pada situasi yang terjadi. Lapses atau selip ialah penyimpangan wujud yang lahir sebab beralihnya pusat atensi topik pembicaraan selama beberapa saat. Sedangkan error atau silap ialah penyimpangan berbahasa yang terjalin secara sitematis serta terus berlanjut karna belum di kuasainya kaidah-kaidah dan juga norma-norma dalam bahasa sasaran. Menurut seorang penutur asli jepang yaitu Kawarazaki (dalam Putri, 2020: 258), saat dia mendengar pembelajar bahasa kedua berbicara atau membaca apa yg pembelajar tersebut tulis, kemudian pembelajar tersebut merasakan kebingungan tentang hal itu, maka itu disebut dengan error.

Dari penjelasan di atas, peneliti ingin menganalisis kesalahan yang terjadi dalam penggunaan doushi dan keiyoushi pada sakubun tersebut. Maka, peneliti bermaksud melakukan riset dengan judul "Analisis Kesalahan Penggunaan Doushi dan Keiyoushi Pada Sakubun Mahasiswa Prodi Pendidikan Bahasa Jepang UNP”.

\footnotetext{
${ }^{1}$ Mahasiswa Prodi Pendidikan Bahasa Jepang FBS UNP lulus pada tanggal 20 desember 2020

${ }^{2}$ Dosen Prodi Pendidikan Bahasa Jepang FBS UNP
} 


\section{METODE PENELITIAN}

Dalam riset ini, jenis penelitian yang di pakai yakni kualitatif. Sutedi (2009: 23) menjelaskan bahwa penelitian yang datanya tidak berupa angka-angka serta tidak perlu untuk diolah dengan memakai metode statistik yakni penelitian kualitatif. Penelitian ini dikatakan kualitatif sebab data pada riset ini berupa kalimat dan bukan berwujud data yang diukur angka.

Metode penelitian yang dipakai pada riset ini ialah metode deskriptif kualitatif. Bogdan pada Meleong (dalam Amelia, 2018: 33) menyebutkan bahwa penelitian deskriptif kualitatif yaitu metode penelitian yang memberikan hasil data deskriptif berwujud perkata tertulis ataupun lisan dari orang-orang ataupun sikap yang diamati. Riset ini termasuk penelitian deskriptif karena penelitian ini hanya menganalisis data dengan cara menjelaskan sesuatu kejadian ataupun fenomena yang ada dengan cara apa adanya.

Zaim (dalam Hardianti, 2019: 30) menyebutkan bahwa data yakni bagian dari fakta-fakta yang dibuat ilmuan sebagai sesuatu yang mempunyai makna. Data pada penelitian merupakan bahan dasar ataupun bahan baku utama guna menerangkan sesuatu fenomena. Data juga menjadi bahan riset yang didapat dengan metode dan tata cara tertentu pada sumber data. Data dari riset ini yakni kesalahan pada penggunaan keiyoushi serta doushi pada kalimat mahasiswa. Sedangkan, sumber data pada penelitian ini yakni sakubun mahasiswa tahun masuk 2019, program studi pendidikan bahasa Jepang di Universitas Negeri Padang. Jumlah sakubun yang diteliti adalah 30, yang berasal dari 30 mahasiswa, prodi pendidikan bahasa Jepang di Universitas Negeri Padang.

Menurut Sugiyono (dalam Amelia, 2018: 34) untuk penelitian kualitatif, yang menjadi insterumen penelitian ataupun alat dalam penelitian yakni peneliti tersebut. Jadi, instrumen terpenting pada penelitian ini yakni peneliti sendiri.

Adapun teknik mengumpulkan data yang dipakai untuk penelitian ini yakni teknik baca serta teknik catat. Sudaryanto (dalam Hardianti, 2019: 31)menyebutkan bahwa teknik baca yakni teknik yang dipakai guna menjelaskan suatu masalah yang ada pada suatu teks ataupun bacaan. Sedangkan, teknik catat dibuat dengan pencacatan pada tabel inventarisasi data yang di lanjutkan dengan klafisikasi. Dalam riset ini, pengumpulan data untuk teknik baca dilakukan dengan cara membaca dokumen berbentuk tulisan yang berwujud sakubun mahasiswa tahun masuk 2019 prodi pendidikan bahasa Jepang Universitas Negeri Padang secara berulang-ulang. Data yang dicatat pada tabel inventarisasi data yakni hasil penemuan dari proses membaca berwujud sampel acak (random sampling) yang selanjutnya di pisahkan berdasarkan jenis serta struktur pada kalimat yang dipakai.

Tak hanya itu, perihal yang termasuk penting dalam penelitian ialah keabsahan atau validitas data. Sugiyono (dalam Istiqro, 2016: 41) mengatakan bahwa validitas data ialah langkah yang digunakan untuk mengolah data dengan tujuan agar data yang diperoleh memiliki kesahihan atau keabsahan data secara ilmiah serta supaya data yang didapat untuk penelitian ini mempunyai validitas serta objektivitas yang besar. Maka dari itu, metode keabsahan data yang dipakai untuk penelitian ini yakni validitas Internal (credibility) berbentuk peningkatkan ketekunan dalam penelitian. Untuk memperoleh tingkat validitas data yang akurat dan absah, peneliti harus meninggikan ketekunan yang artiya melangsungkan pengamatan secara lebih cermat 
serta berkelanjutan. Dngan cara tersebut, maka kejelasan dari data akan bisa direkam secara jelas dan juga runtut. Dengan meninggikan ketekunan tersebut, maka peneliti bisa melaksanakan pengecekan ulang apakah data yang sudah peneliti dapatkan tersebut benar ataupun tidak benar, serta peneliti juga bisa menyampaikan deskripsi data yang cermat serta sistematis mengenai sesuatu yang ditinjau.

\section{HASIL DAN PEMBAHASAN}

\section{Temuan penelitian}

Adapun hasil temuan yang didapatkan setelah melakukan analisis terhadap tugas dan ujian mahasiswa tahun masuk 2019 mata kuliah shokyu sakubun berjumlah 30 yang dimbil dari 30 mahasiswa tahun masuk 2019 prodi pendidikan bahasa Jepang UNP ialah diketahuinya bentuk kesalahan dan jenis kesalahan dalam penggunaan keiyoushi dan doushi pada sakubun yang dilakukan oleh mahasiswa sebanyak 115 kesalahan. Guna lebih jelasnya, bisa dilihat pada tabel di bawah ini.

Tabel1. Deskripsi Kesalahan Doushi dan Keiyoushi

\begin{tabular}{ll}
\multicolumn{1}{c}{$\begin{array}{c}\text { Klasifikasi data kesalahan penggunaan } \\
\text { doushi dan keiyoushi }\end{array}$} & Frekuensi Kesalahan \\
\hline Bentuk kesalahan & \\
Fonologi & 27 \\
Morfologi & 10 \\
Sintaksis & 19 \\
Semantik & 2 \\
Jenis kesalahan & \\
Mistake & 39 \\
Lapses & 19 \\
\hline Total & $\mathbf{1 1 5}$ \\
\hline
\end{tabular}

Berdasarkan tabel di atas, peneliti menemukan kesalahan fonologi dalam penggunaan doushi dan keiyoushi pada teks sakubun mahasiswa tahun masuk 2019 sebanyak 27 kesalahan, kesalahan morfologi sebanyak 10 kesalahan, kesalahan sintaksis sebanyak 19 kesalahan, kesalahan semantik sebanyak 2 kesalahan, kesalahan mistake sebanyak 39 kesalahan, dan lapses sebanyak 18 kesalahan. Dengan total keseluruhan kesalahan yang ditemukan ialah sebanyak 115 kesalahan.

Kesalahan fonologi yang telah peneliti temukan ini ialah sebanyak 27 kesalahan yang terdapat pada data [1], [2], [3], [4], [7], [8], [9], [10], [11], [20], [21], [22], [24], [25], [26], [27], [28], [29], [30], [31], [34], [36], [37], [38], [39], [40], dan pada data [45]. Kemudian, kesalahan morfologi yang telah peneliti temukan ialah sebanyak 10 kesalahan yang terdapat pada data [5], [6], [12], [13], [14], [16], [17], [18], [35], dan pada data [41]. Selanjutnya, kesalahan sintaksis yang telah peneliti temukan pada penelitian ini ialah sebanyak 19 kesalahan yang terdapat pada data [4], [12], [15], [16], [17], [19], [21], [24], [30], [32], [36], [37], [38], [42], [43], [44], [46], dan pada data [47]. Dan data yang terakhir telah peneliti lakukan yaitu kesalahan semantik yang di temukan ialah sebanyak 2 kesalahan yang terdapat pada data [23] dan juga pada data [33]. 
Salanjutnya akan di deskripsikan bentuk dan jenis kesalahan dari penggunaan doushi dan keiyoushi pada teks sakubun mahasiswa tahun masuk 2019 secara terpisah seperti yang terdapat pada tabel berikut.

Table 2. Deskripsi Kesalahan Doushi

\begin{tabular}{ll}
\hline \multicolumn{1}{c}{ Klasifikasi data kesalahan penggunaan doushi } & Frekuensi Kesalahan \\
\hline Bentuk kesalahan & \\
Fonologi & 9 \\
Morfologi & 8 \\
Sintaksis & 7 \\
Semantik & 0 \\
Jenis kesalahan & \\
Mistake & 14 \\
Lapses & 9 \\
\hline Total & $\mathbf{4 7}$ \\
\hline
\end{tabular}

Berdasarkan tabel di atas, dapat diketahui kesalahan fonologi dalam penggunaan doushi pada teks sakubun mahasiswa tahun masuk 2019 berjumlah 9 kesalahan, kesalahan morfologi berjumlah 8 kesalahan, kesalahan sintaksis berjumlah 7 kesalahan, kesalahan mistake berjumlah 14 kesalahan, lapses berjumlah 9 kesalahan. Dengan total keseluruhan kesalahan doushi yang ditemukan ialah sebanyak 47 kesalahan. Selanjutnya akan di deskripsikan bentuk dan jenis kesalahan keiyoushi pada teks sakubun mahasiswa tahun masuk 2019 yakni sebagai berikut:

Table 3. Deskripsi Kesalahan Keiyoushi

\begin{tabular}{ll} 
Klasifikasi data kesalahan penggunaan keiyoushi & Frekuensi Kesalahan \\
\hline Bentuk kesalahan & \\
Fonologi & 18 \\
Morfologi & 2 \\
Sintaksis & 12 \\
Semantik & 2 \\
Jenis kesalahan & \\
Mistake & 25 \\
Lapses & 9 \\
\hline Total & $\mathbf{6 8}$
\end{tabular}

Selanjutnya, dapat diketahui pula kesalahan fonologi dalam penggunaan keiyoushi pada teks sakubun mahasiswa tahun masuk 2019 berjumlah 18 kesalahan, kesalahan morfologi berjumlah 2 kesalahan, kesalahan sintaksis berjumlah 12 kesalahan, kesalahan semantik berjumlah 2 kesalahan, kesalahan mistake berjumlah 25 kesalahan, dan lapses berjumlah 9 kesalahan. Dengan total keseluruhan kesalahan keiyoushi yang ditemukan ialah sebanyak 68 kesalahan.

\section{Pembahasan}

Berdasarkan kesalahan berbahasa dalam tataran linguistik, Tarigan dan Tarigan (2011: 152) mengklasifikasikan kesalahan berbahasa dalam 4 bidang yaitu fonologi, 
morfologi, sintaksis, dan semantik. Untuk bentuk kesalahan tersebut, ditemukan sebanyak 58 kesalahan dalam penggunaan doushi dan keiyoushi pada teks sakubun mahasiswa tahun masuk 2019 yakni kesalahan fonologi, morfologi, dan sintaksis. Kesalahan yang paling tinggi didapatkan dalam penelitian ini yakni kesalahan fonologi sebanyak 27 kesalahan. Kesalahan fonologi yang paling sering dilakukan oleh mahasiswa ialah kesalahan ejaan yakni kesalahan fonem, pengilangan dan penambahan fonem, silabel, dan tanda baca. Setelah fonologi, kesalahan yang juga sering dilakukan ialah kesalahan sintaksis sebanyak 19 kesalahan yaitu ketidaktepatan dalam pemakaian partikel dan kesalahan atau penyimpangan pada struktur kalimat. Kemudian pada kesalahan morfologi, terdapat 10 kesalahan yang dilakukan oleh mahasiswa yakni salah dalam pembentukan kata. Dan kesalahan yang paling jarang dilakukan ialah kesalahan semantik sebanyak 2 kesalahan yaitu kesalahan dalam relasi makna antara beberapa kata dan makna kalimat yang seharusnya. Selain bentuk kesalahan, peneliti juga menemukan beberapa jenis kesalahan.

Corder (dalam Nurwicaksono, 2018:140) mengemukakan bahwa jenis kesalahan berbahasa terbagi tiga jenis, yakni mistake, lapses, dan error. Pada penelitian tersebut, peneliti tidak menganalisis kesalahan jenis error karena peneliti hanya melakukan tes sebanyak satu kali dan tidak berulang-ulang. Jadi, jenis analisis kesalahan berbahasa yang akan diteliti pada penelitian ini hanyalah mistake dan lapses. Untuk jenis kesalahan tersebut, peneliti menemukan sebanyak 57 kesalahan dalam penggunaan doushi dan keiyoushi pada teks sakubun mahasiswa tahun masuk 2019 yakni kesalahan mistake dan lapses. Kesalahan yang paling tinggi didapatkan untuk penelitian ini yakni kesalahan mistake, terdapat sebanyak 39 kesalahan yang dilakukan oleh mahasiswa. Kesalahan tersebut ialah penyimpangan struktur. Selanjutnya,terdapat jenis kesalahan lapses sebanyak 18 kesalahan. Kesalahan tersebut ialah kesalahan yang terjadi karena selip seperti salah tulis.

Jadi, jika direview dengan penelitian relevan, hasil untuk penelitian ini berbeda pada penelitian yang sudah dilakukan oleh Oktaviani, pada tahun 2018, yang berjudul Analisis Kesalahan Perubahan Doushi Bentuk- $\tau$ Pada Siswa Kelas XI IPA 1 SMAN 8 Padang. Dalam penelitian Oktaviani, fokusnya ialah menganalisis kesalahan perubahan doushi bentuk-te pada siswa. Sedangkan pada penelitian ini, peneliti tidak hanya menganalisis doushi saja, namun peneliti menganalisis doushi dan juga keiyoushi secara keseluruhan. Bentuk kesalahan yang ditemukan dalam penelitian Oktaviani adalah bentuk kesalahan morfologi saja sebanyak 180 data. Kesalahan morfologi ini terjadi karena salah dalam pembentukan doushi bentuk-te. Kesalahan ini diduga karena siswa salah memilih pembentukan doushi bentuk-te yang tepat. Sedangkan pada jenis penelitian, Oktaviani menganalisis tiga jenis kesalahan yakni lapses, mistake, dan error. Jenis kesalahan mistake ditemukan 318 kesalahan, jenis kesalahan lapses ditemukan 59 kesalahan, dan kesalahan error ditemukan 89 kesalahan.

\section{KESIMPULAN}

Berlandaskan hasil daripada analisis data, dapat ditetapkan bahwa terdapat 115 kesalahan penggunaan keiyoushi dan doushi dalam sakubun mahasiswa tahun masuk 2019 prodi pendidikan bahasa Jepang UNP. Kesalahan pada penggunaan keiyoushi 
dan doushi tersebut terdapat dalam empat bidang yaitu fonologi, morfologi, sintaksis, dan semantik. Jumlah kesalahan fonologi dalam penggunaannya ialah sebanyak 27 kesalahan, kesalahan morfologi sebanyak 10 kesalahan, kesalahan sintaksis sebanyak 19 kesalahan, kesalahan semantik sebanyak 2 kesalahan, kesalahan mistake sebanyak 39 kesalahan, dan lapses sebanyak 18 kesalahan.

Pada doushi, bentuk kesalahan yang paling banyak muncul ialah kesalahan fonologi sebanyak 9 kesalahan. Untuk jenis kesalahan, yang paling banyak ditemukan ialah mistake sebanyak 14 kesalahan. Sedangkan pada keiyoushi, bentuk kesalahan yang paling banyak muncul juga kesalahan fonologi yaitu sebanyak 18 kesalahan. Untuk jenis kesalahan, yang paling banyak ditemukan ialah mistake sebanyak 25 kesalahan.

\section{Saran}

Berdasarkan kesimpulan yang telah dipaparkan, diharapkan untuk pembelajar bahasa Jepang dalam menentukan penggunaan keiyoushi dan doushi sebaiknya terlebih dahulu mempelajari maksud penggunaan dari keiyoushi dan doushi itu sebelum membuat sebuah kalimat agar mudah dan paham dalam membuat serangkaian kalimat.

Untuk penelitian selanjutnya diharapkan dapat membahas lebih dalam mengenai kesalahan keiyoushi dan doushi dalam teks sakubun sehingga ditemukan solusi untuk memperkecil kesalahan keiyoushi dan doushi tersebut. Selain itu diharapkan juga ada penelitian lanjutan mengenai kesalahan penggunaan keiyoushi dan doushi dalam bentuk lainnya dalam menggunakan objek kajian yang berbeda misalnya pada bunpo, dokkai, dan lain-lainnya.

\section{REFERENSI}

Amelia, Wiwi Dwi, 2018. Fungsi Joshi Wo dalam Buku Cerita Kaguya Hime Karya Nakajima Yuuko. Sekripsi, Padang: Universitas Negri Padang.

Annisac, Nurul, Sitti Fatimah, Hendri Zalman. 2018. "Hubungan Penguasaan Goi dengan Kemampuan Sakubun Mahasiswa Semester III Tahun Ajaran 2017/2018 Program Studi Pendidikan Bahasa Jepang Universitas Negeri Padang”. Omiyage. Vol.1.No 1. Padang: UNP.

Hardianti, Ani, Hendri Zalman. 2019, Analisis Jenis Dan Struktur Kalimat Dalam Sakubun Mahasiswa Semester IV Prodi Pendidikan Bahasa Jepang Universitas Negeri Padang." Omiyage 2.3 Padang: UNP.

Hazni, Keisha, Hendri Zalman, Nova Yulia. 2017. "Analisis Kesalahan Penggunaan Keiyoushi dalam Tes Bunpou Mahasiswa Angkatan 2014 Prodi Pendidikan Bahasa Jepang Universitas Negeri Padang. Skripsi. Padang: Universitas Negeri Padang. 
Analisis kesalahan doushi dan keiyoushi - indah marlina ${ }^{1}$, meira anggia putri ${ }^{2}$

Nurwicaksono, Dwi Bayu. 2018. "Analisis Kesalahan Berbahasa Indonesia Pada Teks Ilmiah Mahasiswa". Eksis; Jurnal Pendidikan Bahasa dan Sastra Indonesia, 2 (2), 2580-9040.

Oktavini, Desi, Damai Yani. 2018. "Analisis Kesalahan Perubahan Doushi BentukTe Pada Siswa Kelas XI IPA 1 SMA Negeri 8 Padang". Omiyage 1.2 Padang: Universitas Negeri Padang.

Putri, Meira Anggia. 2020. " Morphological Errors on Japanese Verb Conjugation to Passive Form at Third-Year Students of Japanese Education Study Program of UNP" Atlantis Press. 2352-5398

Soepardjo, Djojok, 2012. Linguistik Jepang. Surabaya; Bintang.

Sujianto, dan Ahmad Dahidi, 2004. Pengantar Linguistik Bahasa Jepang, Jakarta: Kesain Belanc.

Sutedi, Dedi, 2003. Dasar dasar linguistik bahasa Jepang. Bandung; Humanira.

Sutedi, Dedi, 2009. Penelitian Pendidikan Bahasa Jepang. Bandung: Humanira.

Tarigan, Henrry Guntur. Tarigan. Djago. 2011. Pengajaran analisis kesalahan berbahasa. Angkasa, Badung.

Zalman, Hendri. 2014. Kosa Kata Bahasa Jepang Dasar. Padang ; FBS UNP Pres. 